\title{
Aggregatibacter segnis
}

National Cancer Institute

\section{Source}

National Cancer Institute. Aggregatibacter segnis. NCI Thesaurus. Code C86135.

A species of facultatively anaerobic, Gram negative, rod shaped bacteria assigned to the phylum Proteobacteria. This bacteria is catalase positive, oxidase negative, requires $\mathrm{V}$ factor but not $X$ factor to grow and xylose is not fermented. A. segnis is a commensal org anism of the oral flora and is rarely pathogenic. 